\title{
ANALISIS PENGARUH PENGANGGURAN DAN INFLASI TERHADAP KEMISKINAN DI SUMATERA UTARA TAHUN 2009-2017
}

\author{
Vania Grace Sianturi \\ Program Studi Magister Ilmu Ekonomi, Fakultas Ekonomi, Universitas Sumatera Utara \\ e-mail: paniagrcs020995@gmail.com
}

\section{Abstract}

This study aims to provide empirical evidence of the influence of unemployment and inflation for poverty. The type of data used in this study is primary data with quantitative research method using multiple linear regression analysis technique and test hypotheses processed with Eviews 10. The result of data analysis showed that unemployment and inflation has a significant impact on the poverty. Seen from coefficient of determination that unemployment and inflation for poverty affect $63.95 \%$, while the remaining $36.05 \%$ influenced by the others thay not included in this research.

Keywords: unemployment, inflation and poverty.

\section{PENDAHULUAN}

Kemiskinan merupakan salah satu persoalan kompleks yang sulit dipecahkan oleh banyak negara di dunia. Pada tahun 2005 Bank Dunia menunjukkan bahwa menjelang akhir tahun 1990-an ada sekitar 1,2 miliar orang miskin dari sekitar 5 miliar lebih jumlah penduduk di dunia. Sebagian besar dari jumlah orang miskin tersebut terdapat di Asia Selatan, Sahara dan Asia Tenggara. Di Indonesia, tingginya jumlah penduduk miskin ini disebabkan oleh krisis ekonomi yang terjadi pada tahun 1998, dimana persentase penduduk miskin mengalami suatu kenaikan dari 17,47 persen pada tahun 1996 dan menjadi sekitar 24,23 persen pada tahun 1998.

Sumatera Utara merupakan salah satu provinsi di Indonesia yang memiliki tingkat kemiskinan yang bersifat fluktuatif. Jika dibandingkan dengan provinsi lainnya, Sumatera Utara merupakan salah satu provinsi yang memiliki persentase kemiskinan yang tinggi. Berikut data yang menunjukkan persentase penduduk miskin di Sumatera Utara dalam kurun waktu tahun 2007 sampai dengan 2019.

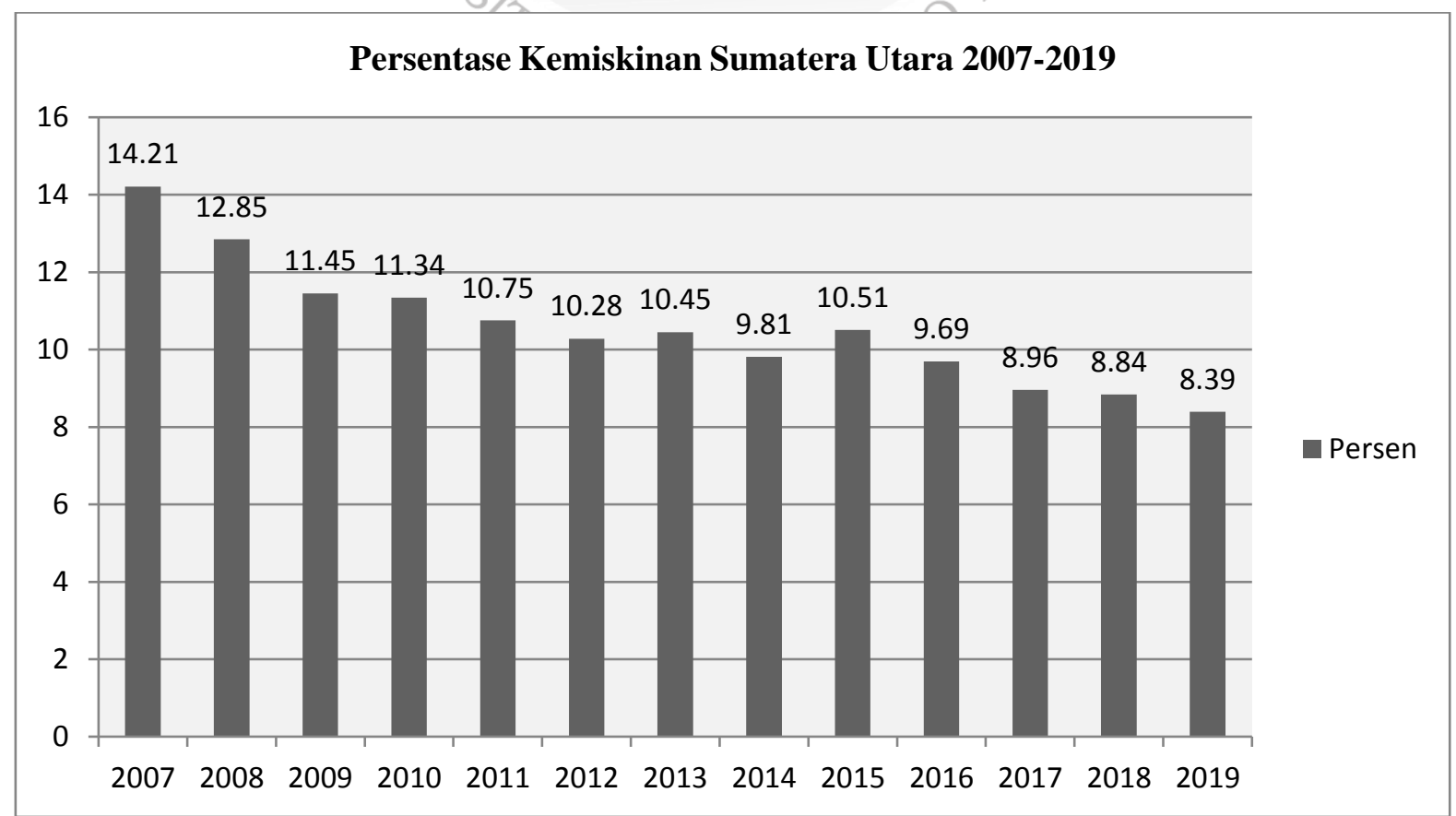

Gambar 1. Peta Kemiskinan Sumatera Utar Sumber : BPS (www.bps.go.id) 


\section{Volume 20 Nomor 2, September 2020}

Tingginya persentase kemiskinan di Sumatera Utara salah satunya disebabkan oleh persentase pengangguran yang terus bertambah. Salah satu penyebab tingginya angka pengangguran adalah tingginya angka pertumbuhan penduduk. Sumatera Utara merupakan provinsi yang keempat terbesar jumlah penduduknya di Indonesia setelah Jawa Barat, Jawa Timur, dan Jawa Tengah. Peningkatan jumlah penduduk di suatu daerah, berarti sama dengan peningkatan terhadap jumlah angkatan kerja. Peningkatan jumlah angkatan kerja yang tidak diimbangi dengan peningkatan jumlah lapangan kerja menjadi salah satu faktor yang meningkatkan persentase pengangguran di daerah tersebut.

Selain dari sisi pengangguran, selanjutnya inflasi juga merupakan salah satu faktor penyebab meningkatnya persentase kemiskinan. Inflasi merupakan suatu keadaan dimana peningkatan terhadap harga suatu komoditi yang terjadi secara terus menerus. Inflasi dapat dikatakan sebagai salah satu faktor penyebab kemiskinan adalah karena ketika harga suatu komoditi mengalami kenaikan secara terus menerus sedangkan penduduk yang memiliki pendapatan tetap bahkan yang tidak memiliki pendapatan akan mengalami kesulitan dalam upaya pemenuhan kebutuhannya.

Berdasarkan masalah di atas, maka peneliti tertarik untuk melakukan penelitian dengan judul Analisis Pengaruh Pengangguran Dan Inflasi Terhadap Kemiskinan Di Sumatera Utara Tahun 20092017.

Rumusan Masalah

Berdasarkan latar belakang yang ada, maka yang menjadi rumusan masalah dalam penelitian ini adalah sebagai berikut:

1. Apakah terdapat pengaruh yang positif dan signifikan antara pengangguran terhadap kemiskinan di Provinsi Sumatera Utara?

2. Apakah terdapat pengaruh yang positif dan signifikan antara inflasi terhadap kemiskinan di Provinsi Sumatera Utara?

3. Apakah terdapat pengaruh secara simultan yang positif dan signifikan antara pengangguran dan inflasi terhadap kemiskinan di Provinsi Sumatera Utara?

Tujuan Penelitian

1. Untuk menganalisis apakah terdapat pengaruh yang positif dan signifikan antara pengangguran terhadap kemiskinan di Provinsi Sumatera Utara.

2. Untuk menganalisis apakah terdapat pengaruh yang positif dan signifikan antara inflasi terhadap kemiskinan di Provinsi Sumatera Utara.

3. Untuk menganalisis apakah terdapat pengaruh secara simultan yang positif dan signifikan antara pengangguran dan inflasi terhadap kemiskinan di Provinsi Sumatera Utara

\section{KAJIAN PUSTAKA}

\section{Pengangguran}

Pengangguran adalah mereka yang masuk ke dalam kelompok yang disebut angkatan kerja dengan kisaran usia 15-64 tahun, yang sedang mencari pekerjaan atau sedang mempersiapkan suatu usaha atau juga penduduk yang tidak mencari pekerjaan karena merasa tidak mungkin mendapatkan pekerjaan atau yang sudah mempunyai pekerjaan tetapi belum memulai bekerja.

Inflasi

Inflasi adalah suatu gejala ekonomi yang menunjukkan kenaikan harga-harga barang dan jasa secara umum dan berlangsung secara terus menerus. Inflasi yang tergolong ringan, biasanya mempunyai pengaruh yang positif yang dalam arti dapat mendorong perekonomian untuk berkembang lebih baik seperti meningkatkan pendapatan nasional dan merangsang orang bergairah bekerja dan berinvestasi. Sedangkan inflasi yang tergolong parah justru dapat mengacaukan perekonomian sehingga mengalami kelesuan.

Kemiskinan

Kemiskinan merupakan suatu kondisi dimana terjadi keterbatasan dan ketidak mampuan seseorang dalam memenuhi kebutuhan-kebutuhan dasarnya seperti sandang, pangan, papan. Kemiskinan bisa disebabkan oleh kualitas sumber daya manusia yang kurang baik atau juga disebabkan rendahnya ketersediaan lapangan pekerjaan. Kemiskinan yang terus menerus berlanjut dapat menyebabkan gangguan dalam hidup sosial, seperti tindak kriminal. 


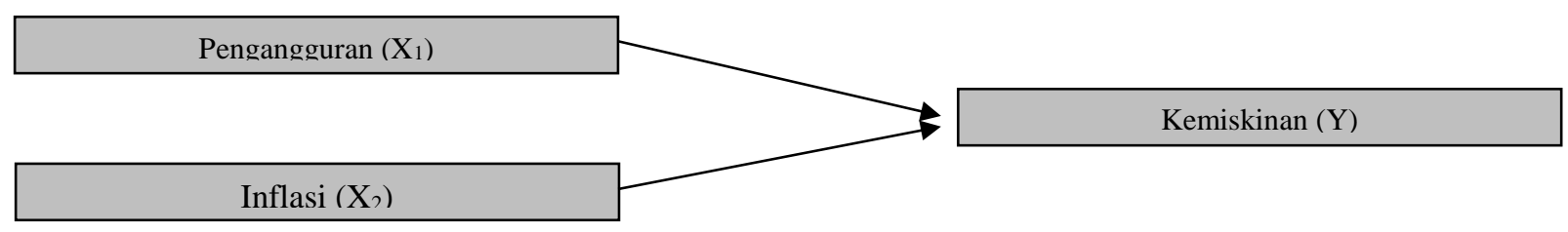

Gambar 2. Kerangka Berpikir

Berdasarkan skema kerangka berpikir di atas,, terdapat dua variabel bebas yaitu penganggutan dan inflasi dan satu variabel terikat yaitu kemiskinan.

Hipotesis Penelitian

1. Pengangguran berpengaruh positif dan signifikan terhadap kemiskinan di Provinsi Sumatera Utara.

2. Inflasi berpengaruh positif dan signifikan terhadap kemiskinan di Provinsi Sumatera Utara.

3. Pengangguran dan inflasi secara simultan berpengaruh positif dan signifikan terhadap kemiskinan di Provinsi Sumatera Utara.

\section{METODOLOGI PENELITIAN}

Penelitian ini mengenai pengaruh pengangguran dan inflasi terhadap kemiskinan. Peneliti melakukan studi empiris dengan obyek penelitian Provinsi Sumatera Utara pada tahun 2007 sampai 2019. Untuk variabel pengangguran akan digunakan nilai persentase pengangguran terbuka, untuk variabel inflasi akan digunakan nilai persentase inflasi dan untuk variabel kemiskinan akan digunakan nilai persentase kemiskinan. Adapun data yang digunakan dalam penelitian ini merupakan data sekunder yang diperoleh dari data publikasi Badan Pusat Statistik (BPS). Teknik analisis dalam penelitian ini menggunakan teknik analisis regresi linear berganda dengan sebelumnya melakukan uji asumsi klasik.

\section{Uji Asumsi Klasik \\ Uji Normalitas}

Mengingat bahwa analisis data yang digunakan dalam penelitian ini adalah analisis regresi linear berganda, maka akan digunakan uji asumsi klasik yang harus dipenuhi syaratnya, yaitu data sudah berdistribusi normal. Data yang dikatakan berdistribusi normal adalah data yang memiliki nilai probablititas $\alpha=0.05$ atau $5 \%$.

\section{Uji Linearitas}

Dalam uji linearitas disyaratkan bahwa pengaruh variabel independen dengan variabel dependen harus saling membentuk kurva linear dengan menggunakan uji Ramsey Test. Adapun dasar dalam pengambilan keputusannya adalah:

1. Dilihat dari nilai signifikannya, jika nilai signifikansi lebih besar dari 0.05 , hal ini berarti terdapat hubungan yang linear antara variabel indepenen dengan variabel dependen. Demikian juga sebaliknya, jika nilai signifikansinya lebih kecil dari 0.05 , hal ini berarti tidak terdapat hubungan yang linear antara variabel independen dengan variabel dependen.

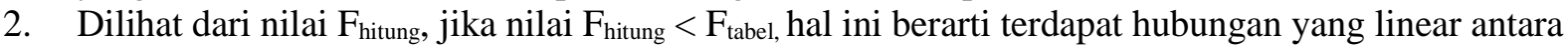
variabel independen dengan variabel dependen. Demikian juga sebaliknya jika $F_{\text {hitung }}>F_{\text {tabel, }}$, hal ini berarti tidak terdapat hubungan yang linear antara variabel independen dengan variabel dependen.

\section{Uji Multikolinearitas}

Uji ini bertujuan untuk menguji apakah dalam model regresi ditemukan adanya korelasi antar variabel independen. Model regresi yang dikatakan baik, seharusnya tidak terjadi korelasi antar variabel independennya. Jika terjadi multikolinearitas, berarti antar variabel independen saling berkorelasi, maka akan sulit sekali untuk mengetahui variabel independen mana yang mempengaruhi variabel 


\section{Volume 20 Nomor 2, September 2020}

dependen. Adapun aturan yang ada di uji ini adalah jikaVIF > 1, maka variabel tersebut mempunyai persoalan multikolinearitas dengan variabel lainnya. Sedangkan apabila diperoleh VIF $<10$ dan tolerance di atas 0.1 , maka dalam model tersebut tidak terjadi multikolinearitas.

\section{Teknik Analisis Data}

\section{Analisis Regresi Linier Berganda}

Analisis regresi linier berganda digunakan untuk mengetahui pengaruh antara dua atau lebih variabel independen dengan satu variabel dependen, serta untuk mengetahui apakah variabel independen masing-masing berpengaruh positif atau negative terhadap variabel dependen. Di dalam penelitian ini maka analisis regresi linier berganda digunakan untuk mengetahui pengaruh antara variabel pengangguran dan inflasi terhadap kemiskinan.

$$
\mathbf{Y}=\mathbf{a}+\mathbf{b}_{1} \mathbf{X}_{1}+\mathbf{b}_{2} \mathbf{X}_{2}
$$

Dimana: $a, b_{1}$ dan $b_{2}$ dapat dicari dengan rumus:

$$
\begin{aligned}
& \mathrm{a}=\mathrm{b}_{1} \mathrm{X}_{1}-\mathrm{b}_{2} \mathrm{X}_{2} \\
& \beta_{1}=\left(\sum X_{2}^{2}\right)\left(\sum X_{1} Y\right)-\left(\sum X_{1} X_{2}\right)\left(\sum X_{2} Y\right) \\
& \left(\sum X_{1}^{2}\right)\left(\sum X_{2}^{2}\right)-\left(\sum X_{1} X_{2}\right)^{2} \\
& \beta_{2}=\left(\sum X_{1}^{2}\right)\left(\sum X_{2} Y\right)-\left(\sum X_{1} X_{2}\right)\left(\sum X_{1} Y\right) \\
& \quad\left(\sum X_{1}^{2}\right)\left(\sum X_{2}^{2}\right)-\left(\sum X_{1} X_{2}\right)^{2}
\end{aligned}
$$

Uji Hipotesis

Uji Hipotesis Secara Parsial (Uji t)

$\begin{array}{llll}\text { Keterangan: } & & \\ \mathrm{Y} & : \text { kemiskinan } & \mathrm{X}_{1} & \text { : pengangguran } \\ \mathrm{X}_{2} & : \text { inflasi } \quad \mathrm{a} & \text { : kontanta } \\ \mathrm{b}_{1} & \text { : koefisien regresi pengangguran } \\ \mathrm{b}_{2} & \text { : koefisien regresi inflasi }\end{array}$

Uji t atau parsial digunakan untuk menguj1 apakah varıabel independen masing-masing mempunyai pengaruh secara parsial terhadap variabel dependen. Dalam pengujian uji t taraf signifikansinya adalah $\alpha=0.05$ atau 5\%. Dengan kriteria jika $t_{\text {hitung }}>t_{\text {tabel }}$ pada taraf signifikan $=.95 \%$ $(\alpha=0.05$ atau $5 \%)$, berarti ada pengauh yang signifikan antara variabel independen terhadap variabel dependen. Namun, $\mathrm{t}_{\text {hitung }}<\mathrm{t}_{\text {tabel }}$ pada taraf signifikan $=95 \%(\alpha=0.05$ atau $5 \%)$, berarti tidak ada pengauh yang signifikan antara variabel independen terhadap variabel dependen.

\section{Uji Hipotesis Secara Simultan (Uji F)}

Uji F digunakan untuk mengetahui apakah variabel independen secara simultan atau bersamasama berpengaruh signifikan atau tidak terhadap variabel dependen. Taraf signifikansi yang digunakan adalah $95 \%(\alpha=0.05$ atau $5 \%)$. Adapun kriteria yang digunakan adalah jika $\mathrm{F}_{\text {hitung }}>\mathrm{F}_{\text {tabel }}$ pada taraf signifikan $=.95 \%(\alpha=0.05$ atau $5 \%)$, berarti variabel independen secara simultan atau bersama-sama berpengaruh terhadap variabel dependen. Namun jika $F_{\text {hitung }}<F_{\text {tabel }}$ pada taraf signifikan $=.95 \%(\alpha=$ 0.05 atau $5 \%$ ), berarti ada variabel independen secara simultan atau bersama-sama tidak berpengaruh terhadap variabel dependen atau hipotesis ditolak.

\section{Koefisien Determinasi}

Koefisien determinasi $\left(\mathrm{R}^{2}\right)$ digunakan untuk mengetahui besarnya pengaruh atau sejauh mana sumbangan variabel independen terhadap variabel dependen dengan adanya regresi linier berganda. Jika $\mathrm{R}^{2}$ yang diperoleh mendekati 1, maka dapat dikatakan semakin kuat model tersebut menerangkan pengaruh variabel independen terhadap variabel dependen, demikian pula sebaliknya.

Hasil dan Pembahasan

Uji Linearitas

Dilihat dari $\mathrm{F}_{\text {statistic }}$ bahwa nilai probabilitasnya adalah sebesar $0.0621>0.05$. Hal ini berarti terdapat hubungan yang linear antara variabel independen dengan variabel dependen.

Ramsey RESET Test

Equation: UNTITLED

Specification: KEMISKINAN C PENGANGGURAN INFLASI

Omitted Variables: Squares of fitted values

\begin{tabular}{lccc}
\hline \hline & Value & df & Probability \\
\cline { 2 - 4 } t-statistic & 1.913535 & 45 & 0.0621 \\
F-statistic & 3.661618 & $(1,45)$ & 0.0621
\end{tabular}


Volume 20 Nomor 2, September 2020

Likelihood ratio

3.833177

1

F-test summary:

\begin{tabular}{lccc} 
& Sum of Sq. & df & Squares \\
\cline { 2 - 4 } Test SSR & 2.478384 & 1 & 2.478384 \\
Restricted SSR & 32.93685 & 46 & 0.716018 \\
Unrestricted SSR & 30.45847 & 45 & 0.676855
\end{tabular}

LR test summary:

Restricted $\log \mathrm{L}$

Unrestricted LogL

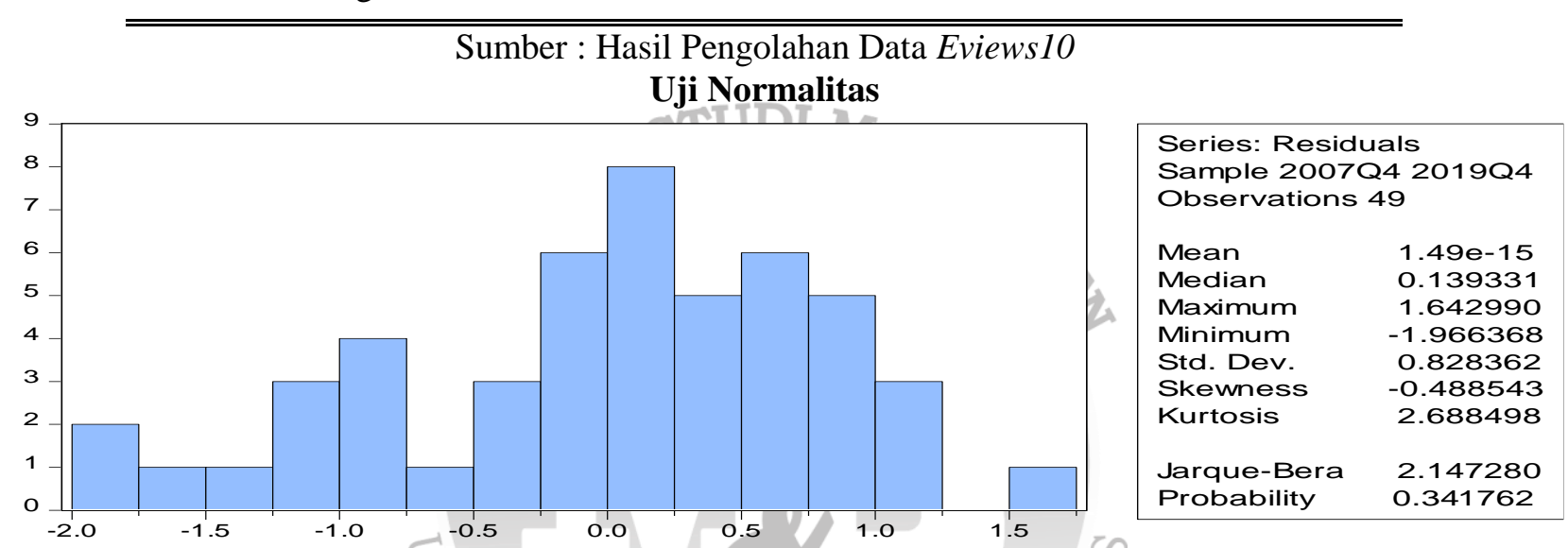

Sumber : Hasil Pengolahan Data Eviews10

Berdasarkan output di atas, dapat diketahui bahwa nilai probabilitas sebesar $0.34>0.05$, sehingga dapat disimpulkan bahwa data yang diuji berdistribusi normal.

\section{Uji Multikolinearitas}

\begin{tabular}{|c|c|c|c|}
\hline \multicolumn{4}{|c|}{$\begin{array}{l}\text { Variance Inflation Factors } \\
\text { Date: 03/27/20 Time: 22:05 } \\
\text { Sample: 2007Q4 2019Q4 } \\
\text { Included observations: } 49\end{array}$} \\
\hline Variable & $\begin{array}{c}\text { Coefficient } \\
\text { Variance }\end{array}$ & $\begin{array}{c}\text { Uncentered } \\
\text { VIF }\end{array}$ & $\begin{array}{c}\text { Centered } \\
\text { VIF }\end{array}$ \\
\hline $\mathrm{C}$ & 0.604236 & 41.35030 & NA \\
\hline PENGANGGURAN & 0.009189 & 35.71133 & 1.001581 \\
\hline INFLASI & 0.002274 & 5.634498 & 1.001581 \\
\hline
\end{tabular}

Sumber : Hasil Pengolahan Data Eviews10

Berdasarkan hasil di atas dapat diketahui bahwa nilai VIF variabel pengangguran dan inflasi yaitu sebesar $1.00<10$. Maka dari itu dapa disimpulkan bahwa tidak terjadi multikolinearitas.

\section{Analisis Regresi Linier Berganda}

Dari hasil pengolahan data menggunakan Eviews10, maka dapat dibuat persamaan regresinya sebagai berikut:

Dependent Variable: KEMISKINAN 


\section{Volume 20 Nomor 2, September 2020}

Method: Least Squares

Date: 03/27/20 Time: 21:58

Sample: 2007Q4 2019Q4

Included observations: 49

\begin{tabular}{ccccc}
\hline \hline Variable & Coefficient & Std. Error & t-Statistic & Prob. \\
\hline \hline C & 4.115412 & 0.777326 & 5.294317 & 0.0000 \\
PENGANGGURAN & 0.618739 & 0.095857 & 6.454797 & 0.0000 \\
INFLASI & 0.333687 & 0.047690 & 6.997064 & 0.0000 \\
\hline \hline R-squared & 0.654582 & Mean dependent var & 10.53296 \\
Adjusted R-squared & 0.639564 & S.D. dependent var & 1.409445 \\
S.E. of regression & 0.846179 & Akaike info criterion & 2.563098 \\
Sum squared resid & 32.93685 & Schwarz criterion & 2.678924 \\
Log likelihood & -59.79590 & Hannan-Quinn criter. & 2.607042 \\
F-statistic & 43.58606 & Durbin-Watson stat & 0.173867 \\
Prob(F-statistic) & 0.000000 & & & \\
\hline \hline
\end{tabular}

$\mathrm{Y}=\mathrm{a}+\mathrm{b}_{1} \mathrm{X}_{1}+\mathrm{b}_{2} \mathrm{X}_{2}$

$\mathrm{Y}=4.115+0.618 \mathrm{X}_{1}+0.333 \mathrm{X}_{2}$

Persamaan regresi linier berganda tersebut dapat diuraikan sebagai berikut:

1. Jika pengangguran dan inflasi $=0$, maka nilai kemiskinan adalah 4.115.

2. Nilai koefisien regresi pengangguran sebesar 0.618 , artinya bahwa peningkatan sebanyak $1 \%$ pada pengangguran dengan asumsi inflasi bernilai tetap atau konstan maka âkan menyebabkan kenaikan pada kemiskinan sebesar 0.618 .

3. Nilai koefisien regresi inflasi sebesar 0.333 , artinya bahwa peningkatan sebanyak $1 \%$ pada inflasi dengan asumsipengangguran bernilai tetap atau konstan maka akan menyebabkan kenaikan pada kemiskinan sebesar 0.333 .

\section{Uji Hipotesis}

\section{Uji Hipotesis Secara Parsial (Uji t)}

Hasil perhitungan uji hipotesis secara parsial berdasarkan tabel menunjukkan bahwa untuk variabel pengangguran diperoleh $t_{\text {hitung }}=6.454797$ atau 6.45 dengan probabilitas $0.000<0.05$, sedangkan nilai $\mathrm{t}_{\text {tabel }}$ pada $\mathrm{df}=\mathrm{n}-\mathrm{k}(49-3)=46$ pada taraf signifikan 0.05 adalah sebesar 2.01. Dari penjelasan di atas dapat disimpulkan bahwa nilai $t_{\text {hitung }}>\mathrm{t}_{\text {tabel }}(6.45>2.01)$. Dengan demikian hipotesis diterima, yaitu ada pengaruh yang positif dan signifikan dari pengangguran terhadap kemiskinan.

Kemudian pada variabel inflasi diperoleh $t_{\text {hitung }}=6.99$ dengan probabilitas $0.003<0.05$, sedangkan nilai $t_{\text {tebel }}$ pada $\mathrm{df}=\mathrm{n}-\mathrm{k}(49-3)=46$ pada taraf signikan 0.05 adalah sebesar 2.01. Dengan demikian hipotesis diterima, yang berarti ada pengaruh positif dan signifikan dari inflasi terhadap kemiskinan.

\section{Uji Hipotesis Secara Simultan (Uji F)}

Hasil perhitungan uji hipotesis secara simultan berdasarkan tabel menunjukkan bahwa $\mathrm{F}_{\text {hitung }}$ sebesar 43.58606 atau 43.58 dengan $F_{\text {tabel }}$ sebesar 3.20. Dari data tersebut dapat diketahui Fhitung > $\mathrm{F}_{\text {tabel }}$ yaitu $43.58>3.20$, maka dapat disimpulkan bahwa pengangguran dan inflasi simultan berpengaruh positif dan signifikan terhadap kemiskinan.

\section{Koefisien Determinasi $\left(\mathbf{R}^{2}\right)$}

Berdasarkan tabel di atas diperoleh angka $\mathrm{R}^{2}$ sebesar 0.639564 atau $63.95 \%$. hal ini menunjukkan bahwa persentase sumbangan pengaruh variabel pengangguran dan inflasi terhadap 


\section{Volume 20 Nomor 2, September 2020}

variabel kemiskinan sebesar $63.95 \%$, sedangkan sisanya $36.05 \%$ dipengaruhi oleh variabel lain yang tidak dimasukkan dalam model penelitian ini.

\section{Kesimpulan}

\section{KESIMPULAN}

Berdasarkan hasil penelitian dan uji statistik, maka dapat ditarik kesimpulan sebagai berikut:

1. Variabel pengangguran berpengaruh positif dan signifikan terhadap kemiskinan di Provinsi Sumatera Utara. Dimana nilai $t_{\text {hitung }}>t_{\text {tabel }}(6.45>2.01)$.

2. Variabel inflasi berpengaruh positif dan signifikan terhadap kemiskinan di Provinsi Sumatera Utara. Dimana nilai $t_{\text {hitung }}>t_{\text {tabel }}(6.99>2.01)$

3. Hasil dari pengujian signifikansi secara simultan (uji F) bahwa pengangguran dan inflasi secara simultan berpengaruh positif dan signifikan terhadap kemiskinan di Provinsi Sumatera Utara, dimana Fhitung $>\mathrm{F}_{\text {tabel }}$ yaitu $43.58>3.20$.

4. Hasil pengujian koefisien determinasi $\left(\mathrm{R}^{2}\right)$ diperoleh persentase sumbangan pengaruh pengangguran dan inflasi secara simultan berpengaruh positif dan signifikan terhadap kemiskinan si Provinsi Sumatera Utara sebesar $63.95 \%$ sedangkan sisanya $36.05 \%$ dipengaruhi variabel lain di luar model penelitian ini.

\section{Saran}

Berdasarkan penelitian yang dilakukan, maka peneliti memberikan saran sebagai berikut:

1. Bagi pemerintah daerah. Untuk memerangi persentase angka kemiskinan yang terus berfluktuasi setiap tahunnya, maka pemerintah daerah sebaiknya mencoba untuk lebih menggali potensi yang ada di Provinsi Sumatera Utara, misalnya saja di sektor pariwisata, UKM, dll yang diharapkan dapat mengurangi angka pengangguran yang tersebar di masyarakat berbagai daerah di bawah naungan Provinsi Sumatera Utara.

2. Bagi peneliti lainnya. Peneliti manyadari masih banyak kekurangan dalam penelitian ini, oleh sebab itu peneliti berharap agar kiranya peneliti berikutnya dapat melanjutkan penelitian ini dengan ruang lingkup yang lebih luas untuk dapat digunakan sebagai bahan pertimbangan pemerintah dalam pengambilan keputusan.

\section{DAFTAR PUSTAKA}

Arikunto, Suharsimi. 2014. Prosedur Penelitian Suatu Pendekatan Praktik. Jakarta : Penerbit PT Rineka Cipta.

Imelia. 2012. "Pengaruh Inflasi Terhadap kemiskinan di Provinsi Jambi". Vol. 1; No. 05; 2012.

Mankiw, Gregory. 2003. Teori Makroekonomi. Jakarta : Penerbit Erlangga.

Paramita \& Purbadharmaja. 2015. “ Pengaruh Investasi dan Pengangguran Terhadap Pertumbuhan Ekonomi Serta Kemiskinan di Provinsi Bali.

Sugiartiningsih \& Shaleh. 2017. "Inflation Influence on Poverty Indonesia Period 1998 - 2014". ISSN-2252-3936.

Tambunan. Tulus. 2012. Perekonomian Indonesia. Bogor : Penerbit Ghalia Indonesia.

Wirawab \& Arka. "Analisis Pengaruh Pendidikan, PDRB Per Kapita dan Tingkat Pengangguran Terhadap Jumlah Penduduk Miskin Provinsi Bali. ISSN: 2303-0178. www.bps.go.id. 